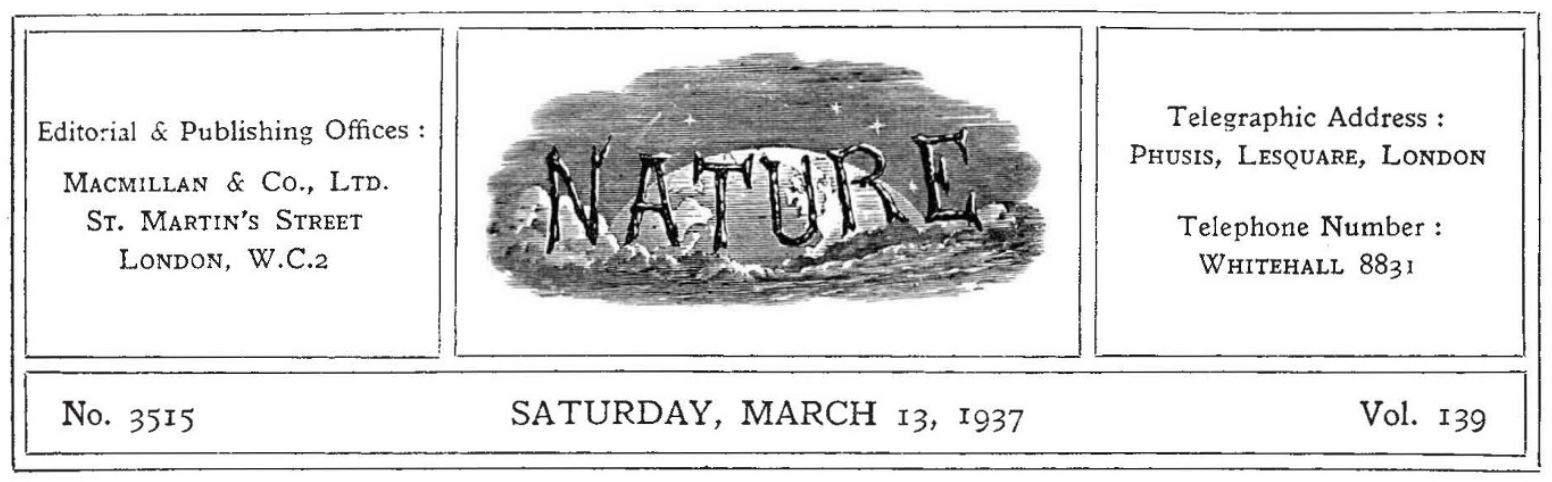

\title{
Librarianship in Relation to Scientific Research
}

$\mathrm{H}^{\mathrm{t}}$ UMAN nature being what it is, the continued existence of a collection of books presupposes the existence of a custodian whose primary instinct and duty is defence. So, no doubt, in the fifth or sixth century were the first librarians regarded; and so, of course, have the members of that profession to-day heavy responsibilities for the safety of priceless literary collections.

Not that all books are to be prized as storehouses of the mind ; some indeed are "no good for reading", whilst others tell us "little that one need know, very much which it would be a positive mistake to believe". There are old libraries that resemble museums of antiquities, where the shelves are so many substitutes for glass cases; the bindings still a delight to the appreciative eye, and the leaves beckoning us to a near-by arm-chair for the pleasure of a dream in the remoter past. In tune with the atmosphere, we would call the venerable student in whose charge we enjoy these treasures by the name of 'library keeper', feeling the usual designation to be a little too businesslike and efficient for our mood. But there are also new libraries which repel or attract us, as may be, with the kaleidoscopic dust-covers of ephemeral fiction purporting to echo the delirium of a feverish modernity; where the keeper of the books cares nothing for their message (perhaps his sense of values is not so false after all) but counts his task well done when he replenishes his stock for fewer pence than his customers are willing to pay for their entertainment. He, too, is a 'librarian', if the title may still be held by a dealer in books, as it once was also by those who copied manuscripts and by their errors planted the seeds of so much perplexity and polemic in later generations. But to-day, if we exclude popular fiction, fewer books are read for pleasure-such is the pace of life and such the competition of other forms of enjoyment-and more for profit, so that our conception of librarianship has undergone a significant change; the custodian of books has come to be recognized for what he really is-a custodian of information. Perhaps the scientific library offers to him at once the most difficult task and the most fruitful opportunity of service in the nation's daily work.

Research, whether it be conceived in an academic spirit or planned to achieve some specific utilitarian purpose, needs for its development a basis of existing knowledge as wide and as deep as can be secured. Study of what is already known is the first step in discovering the unknown; and in that study the research worker needs help in increasing measure as the sources of his information become ever more numerous and heterogeneous. There was a time when the chemist, for example, was both expected and able to read most of the significant original papers in his subject; now he is fortunate if it is possible for him to keep abreast of part of it with the aid both of a voluminous special literature designed expressly for that purpose and of the extensive facilities provided by special libraries.

Yet a collection of books, journals, and pamphlets, while indeed the foundation, is not the only constituent of a scientific library as it is understood to-day. The service which such a library renders to students, investigators, and teachers alike depends for its efficiency on a human factor, the personality and the competence of the library staff; and for that reason, matters relating to their training are of some moment both to research workers and to students, particularly to those 
who may be fitted to serve their science better in a library than at a bench. Librarianship has already a valid claim to be ranked as a learned profession, the preparation for which is appropriately a concern of the universities. For example, the School of Librarianship at University College, London, is now in its eighteenth session, having been established by the Senate of the University of London on the basis of suggestions received from the Council of the Library Association, and opened in October, 1919. The School is "organised so as to give a systematic training on a broad basis to students who are already employed in libraries, record offices, or documentation centres, or who propose to adopt work of this kind as their profession."

The full-time course leading to the University of London diploma in librarianship occupies two years in the case of undergraduates (whose matriculation certificate must attest proficiency in Latin), or one year in the case of approved postgraduate students, whilst part-time students are required to devote from three to five years or two years, respectively, to the diploma studies, due account being taken also of practical experience in library administration. So much importance is attached to such experience that the diploma course includes a period of practical work to be carried out in selected libraries, a new arrangement which has already proved its value, and it is a condition of the award of the diploma that a substantial period of service in a library shall have been performed.

The University of London diploma is not, however, the only hall-mark which members of the profession may acquire. Fellowship of the Library Association is already recognized as indicating a very high degree of competence and experience, and the courses provided by the University of London School of Librarianship are equally available to persons desiring to take the intermediate and final examinations conducted by the Library Association. Here, therefore, are two avenues by which aspirants and those who have already commenced the journey may seek to demonstrate that they have reached that degree of competence which, combined with opportunity, will put them in possession, not of fame, but of the knowledge that they contribute significantly in advancing the world's work and culture. Perhaps when fuller recognition is accorded to the position which trained and experienced librarians occupy as 'key' men and women in unlocking the stores of accumulated knowledge for our instruction and delight; when both library authorities and senior members of the profession make greater use of such an institution as the School of Librarianship for the recruitment of their assistants, then an enhanced status will be associated with greater material rewards.

To this end, however, there must needs be cooperation between employers and teachers; and if the truth must be told-as indeed it shouldthere is here room for considerable improvement. The director of the University of London School of Librarianship, Mr. J. D. Cowley, has recently made a substantial contribution. It is his responsibility to see that his students attain such a degree of familiarity with the principles of librarianship as will equip them to accept service under progressive authorities, and such practice in the application of those principles as will commend them to busy librarians who are thus spared much of the burden of instruction. He has therefore reorganized the syllabus in a manner which experience has led him to regard as desirable, and has devoted special attention to the practical aspects of the work. The new course, which is already in operation, provides lectures and examinations in languages, in English literary history, in cataloguing and classification, in administration (including local government organization and the administration of public, university, and special libraries), in bibliography and in palæography. It includes the period of supervised library experience to which reference has already been made, and makes pro. vision for individual studies or research.

The hope may now be expressed that library authorities will, on their part, make a generous contribution to the further success of this scheme of professional training, helping it to serve more effectively not only the needs of the libraries but also the requirements of the reading public. They can do so, for example, by facilitating participation by junior members of their staffs, by regarding it as a principal source of supply of library officers, and by offering such salaries as will both attract the trained candidate and encourage the University of London to permit the School to expand, both in activities and in numbers, parallel with the demands which the profession of librarianship may make upon it in the interests of a community seeking culture, of a nation demanding progress, and of a world sorely needing that sympathy and understanding which fails where knowledge is lacking. 